\title{
Synthesis
}

\section{A Review of Two Payment Schemes for Watershed Services from China and Vietnam: the Interface of Government Control and PES Theory}

\author{
Vijay K. Kolinjivadi ${ }^{l}$ and Terry Sunderland ${ }^{l}$
}

\begin{abstract}
China and Vietnam have developed some of the most ambitious payments for ecosystem services (PES) initiatives for watershed conservation and forest management. These include the Sloping Land Conversion Programme in China and pilot projects designed to implement Decision 380 and the subsequent national PES law in Vietnam. This study reviews how these two government-driven initiatives are achieving their environment and development objectives in terms of their institutional arrangements, implementation in practice, and sustainability prospects. Although it remains too soon to determine the effects of these programs on watershed services, early evidence indicates that they are resulting in vulnerable land being retired from cultivation supported, in some cases, by considerable contributions to household income. A review of these initiatives has revealed two emerging questions that are relevant within the wider discussion on PES theory: (1) What is the ideal role for government in an evolving socio-cultural and political context? (2) What are the implications of a lack of voluntary participation in government administered PES schemes? Future prospects for harnessing the substantial political commitment for watershed protection toward more strategic, flexible, and long-term sustainable outcomes hinge on the ongoing responsiveness of these governments to stakeholder needs and objectives.
\end{abstract}

Key Words: China; environment; payments for ecosystem services; Vietnam; well-being

\section{INTRODUCTION}

The concept of payment for ecosystem services (PES) has garnered substantial international interest as a cost-effective means to improve environmental management by rewarding people for their efforts in providing ecosystem services of value to human societies (Zilberman 2007). PES was originally defined as a voluntary transaction for a well-defined ecological service, with at least one buyer, at least one provider, and based on the condition that the buyer(s) only pays if the provider(s) continues to deliver the defined ecosystem service over time (Wunder 2005). Although not specifically designed for poverty alleviation, PES has been acclaimed for the role that payments can have in offering service providers diversified livelihood opportunities and greater opportunities for improving their well-being (Pirard et al. 2010). The key to finding such a win-win outcome is a conditional offer of the right mix of incentives in exchange for an alteration in the behavior or activities of specific land users. In this way, PES as a social negotiation and voluntary approach may be more acceptable to potential participants than traditional laws or regulations implemented by government, because both parties can perceive gains from the outcome.

China and Vietnam have been thrust into the global spotlight for the rapid development of their incentive-based environmental policy programs, which have come in the form of what the central governments of both countries call ecocompensation or PES. There has been substantial political determination to expand pilot programs and learn from experiences from local diversification of national schemes for informing both domestic and international environmental policy development (Zhang et al. 2008). Within the last 30 years, these nations have emerged from centrally planned and command economies to become two of the fastest growing economies in East Asia (Van An and Duc 2007). The distinctive feature of the political and economic transitions under way has been a reorientation toward a market economy and parallel decentralization within a set of economic, political, and cultural institutions that remain embedded in a top-down, command configuration. In other words, it has been the opening up of global trade that has dynamically impinged upon traditional political and economic ideologies without necessarily altering the role and influence of the state in directing the process (Painter 2008). This has resulted in mixed public-private arrangements, significant local innovation resulting from increasing demands for services, and an innovative response to the environmental consequences associated with rapid economic development.

The two countries have critical features in common. They share a Confucianist past, socialist-influenced legal and governance structures, geographic proximity, a substantial labor force, and a history of political domination, with Vietnamese leaders often looking to China as a model of ideas and institutions for governance. (Gillespe and Chen 2010). Both nations have seen unprecedented economic growth in recent decades largely resulting from a state-directed transformation toward free market liberalization. The parallel reformation that occurred in China and Vietnam was primarily in response to economic rather than ideological constraints (Gillespe and Chen 2010). Dominated by the agricultural sector, both countries began reforming their centrally planned 
economies in the latter half of the 20th century in response to: (a) the failure of state reforms for collectivization of land, nationalization of industrial and trading establishments, and ideology-driven politics; (b) stagnant economic growth, poor living standards, severe food shortages, hyperinflation; and (c) an opportunity for reform arising from the deaths of influential and ideologically orthodox political figureheads, i. e., Mao Zedong in 1976 and Le Duan in 1986 (Vu 2009).

Associated with economic growth, environmental conditions have deteriorated in both countries as a result of overdevelopment and degradation of natural resources. Other factors related to this deterioration include rapid urbanization, expanding populations, and pressure to develop marginal lands in the absence of land security (Liu and Diamond 2005). Furthermore, integration into international markets has raised competitive pressure to develop resources putting additional pressure on natural resources. For example, the increasing use of fertilizers and pesticides as a feature of modern agricultural technology has exacerbated water quality deterioration (Xiaoyun et al. 2006). The urban-rural and geographic discrepancies of development have created significant pressures to sustain livelihoods in environmentally fragile areas. Indeed, people living in areas identified as sources of valuable ecosystem services are generally poorer than those consumers who currently demand but do not pay for those same services (Xiaoyun et al. 2006). Major inter-related elements of land degradation include soil erosion, deterioration of water resources, deforestation, desertification, and loss of biodiversity (Wang et al. 2004, Nguyen et al. 2008). Governments of both countries have responded to the increasing denudation of natural resources and development inequality by introducing laws, institutional frameworks, and public programs for rectifying the mounting social and environmental problems. The central government in China has taken a proactive approach in attempting to balance environmental and development priorities through the promulgation of numerous resource management laws and environmental standards, in forming a legal basis for environmental protection (PRC 2005). In the 11th Five Year Plan (2006-2010), the Chinese government has stressed the critical importance of delivering both poverty alleviation and environmental objectives as a domestic target (Bennett 2009). Vietnam's government has also recognized this increasing priority with the introduction of relevant laws and regulations and has been successful in slowing down the rate of net forest loss in recent years (Wunder et al. 2005). Although some reforms have been made, the governments of both countries have not yet afforded adequate land tenure rights to parallel the increasing market freedoms of the economy (Banks et al. 2003, Xiaoyun et al. 2006). This has resulted in limited motivation for land users, on both agricultural and forest lands, to manage land with long-term objectives and as a result widespread unsustainable use remains a concern.
We evaluate and reflect on two PES-like schemes for forestrelated watershed services emerging from China and Vietnam. Given the experimentation with incentive-based approaches for water and forest management in these traditionally command-driven countries, we hope to provide insights on how the design and implementation of these programs are achieving their environment and development goals and implications for large scale government-run programs in enhancing the concept of PES from theory to practice. This is assessed through an examination of the schemes' legal and institutional frameworks, implementation in practice, and prospects for long-term sustainability. The national initiatives that are the subject of this paper are the Sloping Land Conversion Program (SLCP) in China and the PES pilots being implemented in association with Decision 380/QD-TTg/2008 in Vietnam. This analysis was undertaken through an extensive literature review of documented case studies.

\section{BACKGROUND}

\section{China's SLCP}

In response to the great Yangtze River flood of 1998, China's central government began to recognize the precarious impacts that farming on steep slopes was having on the loss of ecological services that forests and grasslands provide on sloping lands, particularly the incidence of run-off and soil erosion. In 1999, the government introduced the SLCP also known as Grain for Green or the Conversion of Cropland to Forests and Grasslands Program, becoming the most ambitious of China's ecological restoration efforts with over US $\$ 45$ billion devoted to its implementation (Changjin and Liqiao 2007). It is arguably the world's largest land retirement program and has expanded rapidly since its inception. The program involves the conversion of farmland on slopes of $15-25^{\circ}$ or greater to forest or grassland (Bennett 2008). Farmers have the option of converting sloping cropland into either "ecological forest," defined as timber-producing species such as Robinia pseudoacacia and Cunninghamia lanceolata; "economic forest," i.e., orchards of cash crops like chestnut and orange; or grassland. Compensation involves an annual in-kind subsidy of grain that is differentiated based on region to account for differences in yields. As of 2010, this grain subsidy was set at $2250 \mathrm{~kg} / \mathrm{ha}$ in the Yangtze River Basin and $1500 \mathrm{~kg} / \mathrm{ha}$ in the Yellow River Basin (Xu et al. 2010a). A cash subsidy of approximately US $\$ 43 /$ ha is also provided as well as upfront provision of tree seedlings (Xu et al. 2010a). Depending on the type of conversion that takes place, the period of compensation differs, with ecological forests receiving eight years' worth of cash and grain subsidies, economic forests receiving five years to account for recovery of livelihood benefits associated with forest products, and two years of subsidies for conversion to grassland (Weyerhaeuser et al. 2005). The SLCP has been identified as the first national PES program in the country because it directly engages with 
households and is established on the basis of voluntary participation in terms of farmer choice to be involved and the choice of land management adopted. The program also explicitly recognizes livelihood impacts at the household level, and thus attempts to integrate environment and development objectives (Tao et al. 2007).

\section{Vietnam's pilot projects implementing Decision 380 and subsequent PES legislation}

As a mountainous country with a monsoonal climate, Vietnam's economy is critically dependent on the watershed services provided by forests, especially in rural upland areas where agriculture and hydropower are important sectors (Wertz-Kanounnikoff and Rankine 2008). All forest lands are owned by the state and are contracted to individuals and communities for access, use, and management. Forests in Vietnam are classified into 'special-use' (rùng dâc dung) ${ }^{[1]}$, 'protection forest' (rùng phòng hô ${ }^{[2]}$, and 'production forest' (rùng san xuât) ${ }^{[3]}$. The central government, in a similar way to China's, has made substantial efforts to promote the sustainable development of forest resources and the ecosystem services deriving from their protection. These efforts include Program 661 that aimed to increase forest coverage by five million hectares within a 12-year period from 1998 to 2010 (Decision No. 661/QD-TTg/1998; Wunder et al. 2005). This was an incentive-based program mandating nearly two million contracted upland households to reforest previously forested areas as designated protection and production forests. Although significant improvements in forest cover in upland areas have been achieved as a result of the program, statederived financing was insufficient to cover the opportunity costs of contracted land users, and tenure security (five year contracts) was also insufficient to provide incentives to farmers (Wertz-Kanounnikoff and Rankine 2008).

In 2007, the Vietnamese Government demonstrated its commitment toward developing a national PES policy by issuing Decision No. 380/ QD-TTg/2008. It contained legal, institutional, and financial guidelines pertaining to PES and emphasized establishing market-style trades through the valuation of ecosystem services (Gamez 2007). Water flow regulation, soil erosion reduction, and scenic landscape values were specifically identified as critical forest watershed services and were economically measured according to these values (Xuan and Santiago 2010). It aimed to identify sustainable financial mechanisms to achieve forest protection targets and specifically called for the piloting of PES schemes in Son La and Lam Dong provinces from 2008-2010. These provinces were identified for PES pilot testing because of the high demands of municipal water use from major population centers and hydropower developments, as well as their potential to integrate land-management activities with biodiversity conservation and tourism from nearby national parks (Nguyen et al. 2011). Accordingly, three classes of "buyers" were identified: hydropower facilities, water suppliers, and tourism companies. The lessons obtained from the field testing of PES would be used to fine-tune national PES policy for subsequent replication nationwide (Gamez 2007). In this regard, the national PES programs in Vietnam differ from the SCLP in that they are pilots to inform a national law. In September of 2010, the perceived success of pilot implementation associated with Decision 380 culminated in the national 'Payments for Forest Ecosystem Services' Law (Decree 99-CP, 2010).

\section{EVALUATION OF SLCPAND DECISION 380 PILOTS}

\section{Legal, institutional, and administrative frameworks}

\section{Sloping Land Conversion Program}

Line agencies at prefecture, county, and township level as well as provincial and local forestry departments were designated to implement the SLCP through provincial and locally specific regulations (Weyerhaeuser et al. 2005; Fig. 1). Multiple agencies were involved in the process and include departments from forestry and grain supply, to finance and land management, including the Ministry of Land and Resources, the Ministry of Agriculture, the State Forestry Administration (SFA), and the Ministry of Water Resources (Wang et al. 2004). Agencies are tasked with releasing compensation in cash and grain, managing land contracts with farmers, mediating disputes, selecting and measuring land area for conversion, distributing saplings or grass species, issuing contracts, and monitoring results of conversion (Weyerhaeuser et al. 2005). Local institutional units reflect local capacities, resources, and uniquely crafted SLCP implementation regulations.

No specific legislation exists offering guidance on the establishment of PES-like approaches in China (Zheng and Zhang 2006). Although complete ownership rights of natural resources and lands belong to the state, the SCLP has provided for use and management rights during the period of the SLCP contract only, rather than ownership rights to the land in perpetuity (PRC 2005). According to this policy of 'whoever plants maintains and benefits,' land-users are allowed to manage and benefit from the products and services on their assigned land (Xiaoyun et al. 2006). In practice, application of de facto tenure has been found to differ significantly across local contexts (Scherr et al. 2006).

\section{Decision 380}

Decision 380 established the baseline for a national legal framework for PES. It expounds on what is meant by 'forest ecosystem services' (FES) and the rationale for payments; clearly defines the responsibilities and rights of parties to the contracts; defines the method of payment calculation, form, and duration of payments; manages and implements payment transactions, the roles of implementing agencies, and the budget in relation to the source of financing (Government of Vietnam 2008). Because few countries have experimented 
Fig. 1. The Sloping Land Conversion Program's (SLCP) complex administrative and implementation framework used to determine participation, target areas for inclusion, and distribute payments. Local practices and provincial decisions for implementation vary considerably. Sector-specific initiatives embedded within agency development strategies have typically not been analyzed and rectified for inconsistencies and gaps prior to roll out of the SLCP. Once approved, plans are sent back to prefecture level (9-20 per province); counties themselves have between 10-30 townships under their jurisdiction; 15-30 villages under each county, and groups of households called Xiaozu within each village that, rather than households, may hold actual proprietary or managerial rights to land (Agarwal and Ostrom 2001, Wang et al. 2004, Weyerhaeuser et al. 2005, Zhang et al. 2008; B. Lohmar, C. Nickerson, E. Uchida, and X. Jintao, unpublished manuscript).

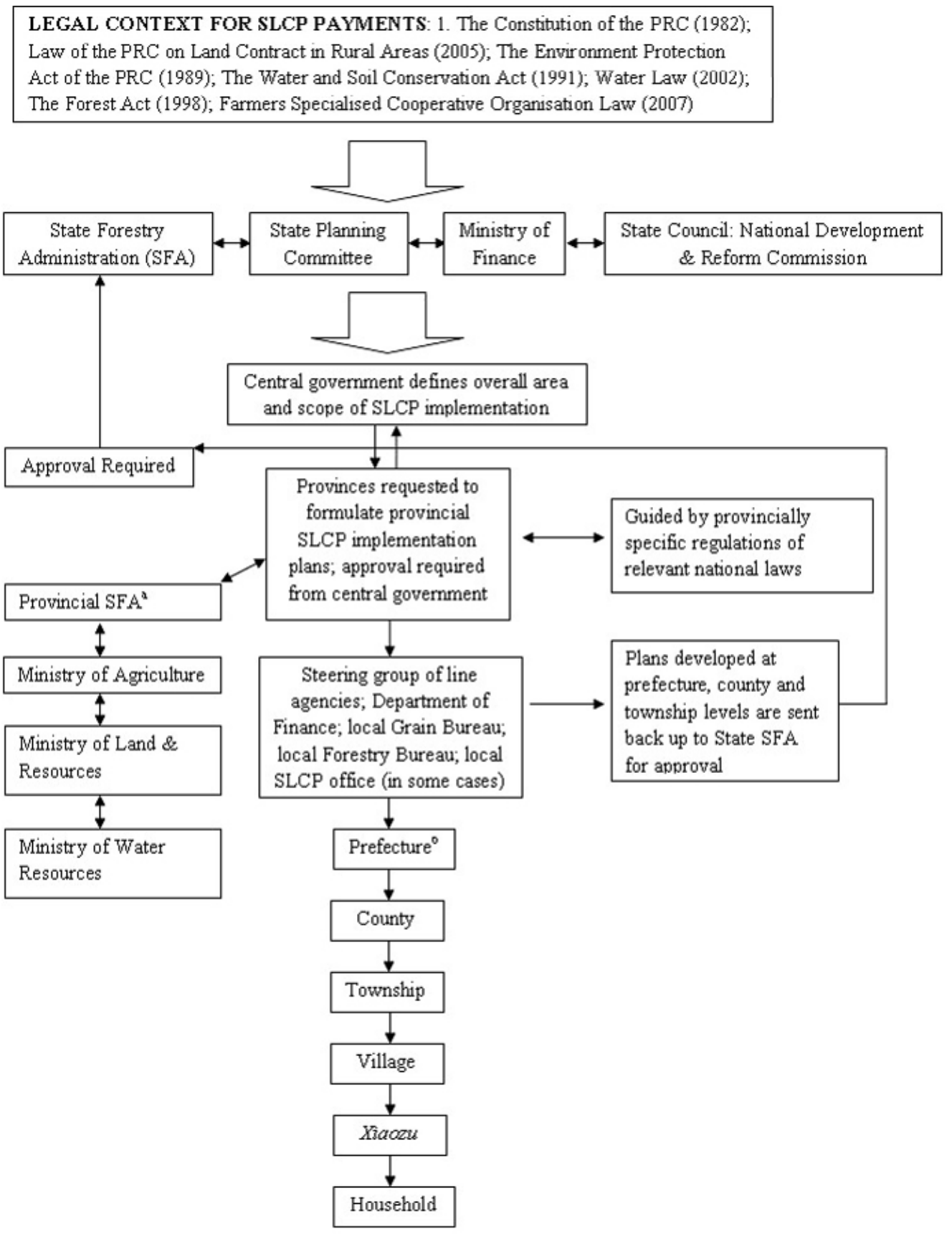


with specific PES laws and directives, Vietnam's Decision 380 offers a commanding step ahead in the direction of establishing legal certainty for applying PES (Greiber 2009). It not only suggests a significant role for government agencies at all levels to facilitate the transactions, but also encourages payments based on direct negotiations between beneficiary and provider. The incorporation of external funding from donors and international NGOs also represents a shift to diversifying resources beyond the government.

Even though Decision 380 endorses the bringing together of service beneficiaries and potential service providers for PES transactions based on voluntary negotiations, contradictory language in the document seems to suggest precisely the opposite. The language of 'need' peppered throughout the text of Decision 380 implies mandatory participation for both entities. Article 3 specifically names the entities to be considered as 'payers' within the pilot schemes (hydropower, water utility, and tourism entities); whereas Article 20 asserts that organizations, households, individuals, and village communities located within the identified pilot watershed sites are "liable before the law for the implementation of the pilot policy as stipulated in this Decision" (Government of Vietnam 2008). A related concern is whether revenue is to be obtained from government administered fees and taxes, or whether it derives from perceived ecosystem service values as conceived through negotiation between service beneficiaries and service providers who manage their land holdings for this purpose. If the latter case, existing laws are sufficient for incentive-based negotiations for ecosystem services. If the former, land use managers will not have rights to retain revenues from the trade because the state sets fee and tax rates and will retain all the revenue from them (Hoang et al. 2008). Considering that Decision 380 dictates specified payment rates to be made from specific stakeholders, it appears the fee and tax approach has been adopted (Pham et al. 2008). Overall, although the legal and political commitments to PES in Vietnam are clearly commendable, the fact that participation does not appear to be based on voluntary negotiations as well as the lack of clarity about who owns revenue casts doubt on the long-term success of these schemes.

An expansive institutional framework was established to administer the pilots of Decision 380. The Ministry of Agriculture and Rural Development was commissioned to take the lead by collaborating with other ministries, including the Ministry of Natural Resources and Environment, Ministry of Planning and Investment, Ministry of Finance, and Ministry of Information and Communication, to prepare final recommendations for the national PES policy based on the pilot implementation (Pham et al. 2008). The requirement for horizontal collaboration of agencies presents a formidable challenge to effective and efficient PES implementation given the complexity of interaction and bounded rationality of institutional thinking (Rees 1990; Fig. 2).
Fig. 2. The institutional arrangement for implementing pilot schemes under Vietnam's Decision 380 and subsequent payments for ecosystem services (PES) law. DARD = Department of Agriculture and Rural Development; DONRE $=$ Department of Natural Resources and Environment; MONRE = Ministry of Natural Resources and Environment; MPI = Ministry of Planning and Investment; MOF $=$ Ministry of Finance; MIC $=$ Ministry of Information and Communications (Pham et al. 2008, Nguyen et al. 2011)

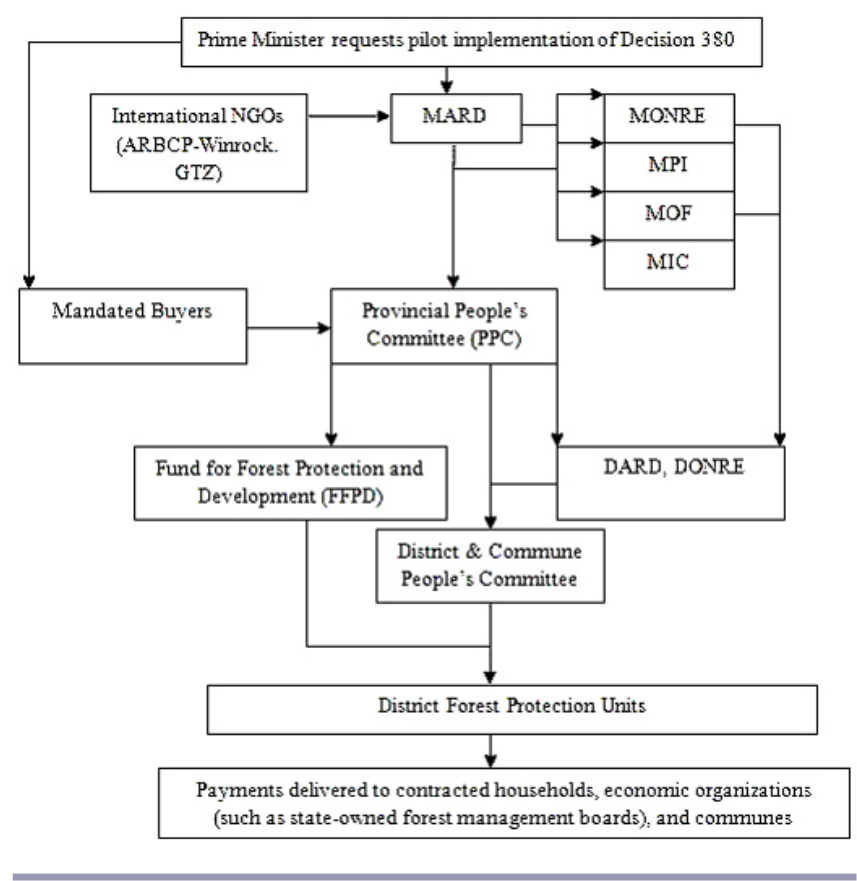

The construction of such a complex institutional configuration for implementation is partly a necessity considering the highly restrictive land use rights situation in Vietnam. The degree to which benefit can be derived from forests depends on the land user group, defined as individuals/households, business interests, or communes/communities; forest classification, i. e., special-use, production, or protection; forest type, natural or planted; forest allocation mode, leased, assigned, or contracted; and source of investment, own funding or state provided (Pham et al. 2008). Land use rights allocations are more restrictive for certain groups than others. Businesses, largely state-owned, and individuals have fewer restrictions on entering into contracts than do communities. This is an unfortunate restriction, given that institutional arrangements that involve local communities in PES can aid in the reduction of transaction costs by providing the social and physical infrastructure to enhance well-being-environment synergies (Ostrom 1990, Bracer et al. 2007, Brondizio et al. 2009, Clements et al. 2010). 


\section{Implementation}

\section{Sloping Land Conversion Program}

The considerable political support and ambitious targets for the SLCP partly explain the rapid expansion of the program over the past decade (Uchida et al. 2007). These numbers are indeed impressive. From an initial pilot phase conducted in 2001 in three provinces located in upper reaches of the Yellow and Yangtze Rivers, sloping land conversion to forests and grasslands was occurring across 25 provinces by 2006 . The rate of conversion has also jumped by more than sixfold over the same period (Bennett 2008). Local implementation is diverse and largely undocumented, with variable outcomes and effects on the achievement of stated program objectives. The huge range of socioeconomic, ecological, and resource opportunities and constraints characteristic of any particular locality makes it extremely difficult to draw firm conclusions about SLCP implications based on limited existing documentation. One positive trend has been the observation of overlap in subscribing low yield production plots, and associated low opportunity costs for farmers with highly sloping land. This effect has tended to maximize positive environmental benefits while reducing costs to farmers (Xu et al. 2004, Uchida et al. 2005). However, this efficiency is tempered by several recurring observations from implementation of the SLCP in practice.

A first consideration relates to the primary objective of the SLCP in reducing soil erosion and sedimentation from sloping lands into major watercourses. The massive scale of the program as well as the size of the subsidies has certainly resulted in the removal of sloping land from cultivation, but it is less clear if associated afforestation has resulted in improved watershed protection (Fu et al. 2004, Long et al. 2006). Gross oversimplification of land use hydrological relationships combined with underestimations of local geology, existing land use practices, and other biophysical characteristics render the ecological arguments of the SLCP to be questionable at best. The ability of forests to reduce soil erosion and decrease the frequency of floods depends critically on their management and the size of the watershed basin (Postel and Thompson 2005). On extremely steep slopes, erosion rates are often independent of land cover, and it remains unclear whether tree planting would be of added protection value (Bruijnzeel 2004). Furthermore, because of the overemphasis placed on planting trees on sloping land, attention to local conditions has largely been ignored. Other ecological management options that focus on restoring and enhancing an appropriate composite of vegetation cover to reduce soil erosion may be more effective in achieving objectives than planting trees. For example, in the semiarid Loess Plateau region of the northwest, afforestation, particularly of timber-producing species, could in fact reduce the water conservation function of soil or lead to further desertification and subsequent tree death (Jiao et al. 2012).
Indiscriminate use of a single species has promoted a monoculture approach to afforestation, which has dubious effects on watershed services coupled with limited biodiversity value. At worst, such an approach would negatively impact overall landscape biodiversity, encourage pest outbreaks, and influence local climatic changes (Weyerhaeuser et al. 2005). Although there have been assertions made about reduced soil erosion over the last decade, the absence of baseline monitoring of the distribution and classification of pre-SLCP forests within the targeted areas limits the ability to substantiate claims (Uchida et al. 2007, Li et al. 2010).

These problems are compounded by the (in)actions of those in charge of implementation. Rural tax reform policy along with specific provisions in the SLCP plan have resulted in the inability of local governments to levy fees on farmers for various activities as they have traditionally done (Tao and Qin 2007). The lack of tax inflow and increasing budget deficits has meant that financial incentives associated with the SLCP has been a lure for already financially strapped local agencies under ever increasing pressure to implement sloping land conversion. Xu et al. (2010a) have observed in SLCP sites across several provinces, the prevalence of local governments hoarding subsidies, or 'rent-seeking,' to meet funding needs. In turn, budget deficits have also created incentives for governments to expand SLCP enrollment quotas to increase funding from the central government (SFA; Xiaoyun et al. 2006). A clear consequence has been greater efforts by local implementing agencies to fulfill their conversion quotas and make efforts to bargain for more subsidies, influencing the massive expansion of the program (Changjin and Liqiao 2007). This scale of expansion not only obscures underlying problems associated with insufficient capacity of local governments to fulfill basic implementation requirements, but also distorts how the conversion is targeted and the necessities of monitoring and enforcement (Bennett 2008). Several studies have also revealed poor survival rates of planted trees, with rates below the SLCP standard for subsidy disbursement (Weyerhaeuser et al. 2005, Bennett 2008). The cause for poor survival rates reflects poor quality sourcing of seedlings and lack of technical support, both aspects reflecting poorly resourced implementing agencies (Bennett 2008). The budget crisis of local government has left local agencies additionally powerless in consulting with farmers, providing sufficient technical assistance on tree planting and maintenance, and has resulted in minimal monitoring and enforcement of the SLCP.

A fundamental concern arises when considering the juxtaposition of a priori government targets for conversion and the voluntary participation of potential service providers that embodies SLCP objectives. County governments specify the number of hectares for conversion to townships, which in turn allocate these to villages. To reduce transaction costs of implementation, local government and forestry bureaus 
stipulate that conversion of land take place in contiguous parcels as was the case in Nujiang prefecture in Yunnan Province (Weyerhaeuser et al. 2005). As such, some farmers are forced to subscribe to the scheme both by their neighbors and by village councils who are themselves required to meet specific conversion targets originating from higher levels of government rather than based on local conditions, land use practices, or household needs. Zhang et al. (2008) revealed that over $80 \%$ of sampled farmers in Ningxia province were not given a choice to participate in the SLCP. Xu et al. (2004) also revealed that a significant number of households surveyed in the original provinces of SLCP piloting (Sichuan, Gansu, and Shaanxi) revealed that they were given little choice of whether to participate or not. Thus, inadequate attention to household empowerment in design and implementation, transparent finance bridging to local governments, and consideration of maintaining forested land upon the eventual cessation of subsidies are key to understanding the likelihood of sustainable outcomes in the SLCP.

\section{Decision 380}

The implementation of Decision 380 has resulted in payment flows in excess of VND 62 billion (US\$2 million) within one to two years. The decision stipulated that the Provincial People's Committees (PPC) of Lam Dong and Son La Provinces were to approve and organize the design and implementation of pilot PES schemes in the headwater areas of the Dong Nai and Da rivers, respectively. Lam Dong identified an area of the Dong Nai upstream of Ho Chi Minh City and adjacent to Cat Tien and Bi Doup-Nui Ba national parks and Vinh Cuu Nature Reserve. A total of 545,657 ha of forest area were identified, which corresponded to the watershed districts in which the identified buyers, i.e., hydropower plants, water supply plants, and forest-related tourism businesses, were located (Government of Vietnam 2010). Son La identified a total area of 397,292 ha in the headwaters of the Da River suitable for inclusion in the pilot, corresponding to the presence of both hydropower facilities and a water supply company (Liss 2008). Because pilot implementation was commissioned for a very short period (2009-2010) and because of the very primacy of payments delivered and land management enacted, it is clearly difficult to make substantive evaluation assessments. However, a number of salient issues of implication for subsequent national application can be identified.

In Lam Dong, sensitivity to the rehabilitation of critical ecological habitats was incorporated through enhancement of agricultural land to improve ecosystem connectivity between two national parks within the watershed zone. Communitylevel awareness raising campaigns combined with capacity building and specialized training for forest owners in watershed monitoring and field surveying was also carried out. Intermediaries offered a unique set of technical skills and were reported to be essential in meeting informational requirements of stakeholders (Pham et al. 2010).

At the same time, serious implementation problems have been encountered. Most pertinent of these concerns relate to (1) the poor clarification of forest status, and (2) the imprecise clarification and realization of voluntary transactions. First, the actual area of forest differed significantly from forest holdings on paper, making it difficult to identify forest areas belonging to a specific owner or contracted households, and thus rendering implementation of payment transactions a substantial challenge. The process of catching up with poor forest status documentation, delineation, filing, and approval has meant that significant time and costs have been incurred (Nguyen et al. 2011). Moreover, insufficient delegation of funds to PPCs has drained financial resources for prompt implementation. Without clear rights to forest holdings, the distribution of payments would not be constitutional and conflicts associated with payment entitlements could potentially lead to further forest degradation (Salzman 2005, Government of Vietnam 2010). The Asia Regional Biodiversity Conservation Program, in reporting on the implementation of the pilot at Lam Dong, stated that forest owners and management boards could voluntarily subscribe to the pilot, though it is less certain whether households that received forest contracts were capable of doing so as well. The lack of any mention of voluntary participation in Decision 380 substantiates this concern (Pham et al. 2010).

\section{Livelihood impacts and sustainability}

\section{Sloping Land Conversion Program}

The SLCP was initially an ecologically oriented program designed to reduce sedimentation and enhance the delivery of watershed services provided by halting agriculture on sloping land. However, because traditionally poor households were pushed into marginalized sloping regions upland of China's main watersheds, the program is indirectly targeting the poor. Whether livelihoods of these poor farmers are truly being enhanced by the scheme is dependent on (a) the opportunity for alternative livelihoods after taking land out of agricultural production (substitution capacity) and (b) the time interval over which payments are made for de-linking economic constraints from ecological degradation (Uchida et al. 2007). High levels of payment, exceeding the opportunity cost from revenue earned in the year prior to land enrollment, have been a frequently recognized characteristic of the SLCP (Wu and Ding 2003, Uchida et al. 2005, Xu et al. 2006a, Changjin and Liqiao 2007, Bennett 2008). Indeed, some farmers were overcompensated and believed lower payments were sufficient to offset their opportunity costs. Grosjean and Kontoleon (2009) showed that households in Guizhou Province were willing to subscribe to the scheme even in the absence of monetary payments but called for enhanced usage and rental rights over the lands they reforest. In some cases, 
as in the relatively poorer province of Ningxia, real net income increased by up to $75 \%$ one year after land enrollment (Uchida et al. 2005). In a survey of nearly 10,000 families within 16 selected counties in Yunnan Province, 95\% 'liked' the SLCP and believed payments should continue with improvements in market access, land tenure, subsidy duration, and greater selfselection of tree species (Zhao 2008). In this respect, subscription to the SLCP represents a critical livelihoods decision for farmers so long as subsidies are delivered on time and as promised. An important caveat however, relates to the geographic and interhousehold variability in production and opportunity costs affecting how compensation was perceived.

Because the SLCP requires farmers to forego cultivation and replace this activity with vegetation cover, i.e., trees or grasses, in exchange for compensation, a question is inevitably raised as to what productive activities farmers will engage in to substitute for previously productive activity. The government has recognized the impact that both land retirement and subsidy income would have on local economic development and food security and has thus urged local governments to initiate strategies that encourage off-farm business enterprise development, alternative agriculture, and broader rural development programs. However, with local governments cash-strapped to implement the SLCP, support for new livelihood opportunities has not been adequate (Zhang et al. 2008). Empirical analysis suggests that the development of new economic activity following land retirement is subject to a number of constraints. Uchida et al. (2007) and Xu et al. $(2006 a, 2010 a)$ reveal that poorer farmers in their samples were both intensifying cultivation on remaining land and otherwise shifting activity from cultivation to husbandry and housing assets as a result of the payments. A prominent finding of these studies was limited evidence for the enhanced uptake of off-farm activities despite incentives and labor savings offered by the SLCP. Farmers require more than financial compensation to prompt structural transitioning beyond farming. A sample of poor farmers from Ningxia province revealed that more than $50 \%$ would consider earning wages through other means upon retiring crop land if they could obtain adequate social support to do so (Zhang et al. 2008). Strong social relations and political empowerment that facilitate access to information, investment in building shared visions of the future, providing access to technology and new markets are fundamental constraints to the adoption of alternative income-generating activities. If the objective of the SLCP is to lift rural households out of poverty, the development of these assets to provide new employment opportunities for poor farmers is critical to avoid reinstating the poverty-ecological degradation cycle once subsidies cease. Moreover, such opportunities rely critically on sufficient social capital to ensure community integrity without risking migration to more urbanized areas. As long as these assets are lacking, typically risk averse farmers would concentrate on productive activities that reflect their existing capacity and level of expertise (Zhang et al. 2008, Bennett et al. 2011).

As payments extend to a maximum of eight years, rising opportunity costs will begin to influence farmers' subsequent actions under a context of land insecurity. In Yunnan Province, sampled farmers were concerned about the future of the program, arguing that the subsidy period was too short for trees to yield sufficient harvest and to compensate fully the losses associated with foregone cultivation (Weyerhaeuser et al. 2005). Where farmers received inadequate compensation or were coerced into program adoption against their will, the likelihood for reconversion to cultivation was even more likely unless profitable noncropping uses of labor are identified during the payment period (Chen et al. 2009). Zhang et al. (2008) found that in Ningxia Province that $26 \%$ of households planned to definitely reconvert enrolled land to cropland when payments ceased, with only $8 \%$ firmly believing they will maintain the trees or grasses with or without payment. Of sampled farmers in Guizhou Province, 34\% responded that they would reconvert land if payments were discontinued (Uchida et al. 2005). Interestingly, decisions to reconvert land correlated strongly with perceptions of land security, with over $60 \%$ either totally unsure about their land rights or sure only during the period of SLCP subsidies (Zhang et al. 2008).

The connection between State Grain Bureau grain supply and government investment for funding the SLCP raises ambiguity in determining government priorities and subsequent confidence in the sustainability the SLCP for ecological rehabilitation. The linkage of agricultural and ecological objectives of the SLCP has sparked a significant debate among Chinese policy makers as to the effect that set-aside is having on food security (Xu et al. 2006b). Indeed, it was certainly the influence of grain price hikes in late 2003 and concerns over food availability that prompted the central government to cut back SLCP subsidies (Feng et al. 2005). The consequent rapid expansion and contraction of the program exemplifies the reactive and project-oriented emphasis reminiscent of past central government initiatives, rather than the need to sustain strong social-ecological governance arrangements across spatial and temporal scales.

Decision 380

Decision 380 makes a concerted effort to integrate development concerns with the use of incentives to sustain the flow of forest watershed services. Average annual payments per household represented a nearly $400 \%$ increase over previous forest protection and management incentives through Program 661 (Nguyen et al. 2011). Locations chosen for pilot implementation conferred particular emphasis on minority groups and involvement by women, as in Lam Dong where nearly $70 \%$ of targeted households belonged to the K'Ho ethnic minority. In addition to payments for forest protection 
and management, the pilot at Lam Dong is promoting the development of a number of commercial contracts between farmers and private enterprises, whereby farmers would deliver raw materials and finished products such as bamboo handicrafts, essential oils, and processed cacao to markets in Ho Chi Minh City (Nguyen et al. 2011). Additionally, efforts were made to integrate new market opportunities with agroforestry systems for the largely forest-dependent households. An important side benefit of this conservationfriendly development initiative has been the enrichment of buffer zone areas to Cat Tien National Park, located within the pilot site at Lam Dong (Nguyen et al. 2011). Although these are certainly positive developments, it remains too early to determine whether the gains of any new enterprises established can be maintained or even whether the livelihood benefits derived from these new opportunities are adequate to meet household needs and improvements in perceptions of well-being.

The implementation of Decision 380 warrants discussion about the implications for Decree 99 and the sustainability of applying similar PES-like schemes nationwide. Despite the positive examples of new livelihood opportunities exemplified in the Lam Dong pilot, little specification exists within the framework itself or within Decree 99 to stimulate new opportunities for livelihoods and well-being enhancement. Indeed, considering the impact that pilot implementation has illustrated for poverty alleviation, it is particularly salient that the agency commissioned with poverty reduction in Vietnam, i.e., the Ministry of Labor, Invalids and Social Affairs, is absent from the institutional arrangements for Decree 99. Furthermore, it cannot be expected that proactive and sufficiently resourced NGOs and donors will be available to facilitate new livelihood opportunities in every PES context that emerges from Decree 99. As Pirard and Billé (2010) argue, pilot PES projects are often implemented under a unique context of substantial public and private financing that is unlikely to be duplicated or to be available at a sufficient scale to result in structural changes. In the case of Decision 380 , the highly command-driven approach dictating the behavior of specific entities rather than devolving collective governance rights to local communities gives very little room for new social norms to guide endogenous demand for incentive-based negotiations, as the Decision 380 deliberately advocates.

\section{REFLECTIONS FOR THE GLOBAL DISCUSSION AND DEVELOPMENT OF PES}

A question arises as to where the programs identified from China and Vietnam fall within a general understanding of PES objectives. Two major conclusions are discussed: (1) the influence of large-scale third party control over the identification of transaction costs in design and implementation, and (2) the implications of mandatory versus voluntary participation in a PES scheme. Given that farmers reside on state-controlled land and are required to adhere to central government guidelines on land usage, doubts exist as to whether land users are indeed 'service providers' who have an individual or collective choice in making livelihood decisions that influence their long-term welfare or whether they are instead a contracted labor force to temporarily manage state forestland. Because of the lack of full user rights to land holdings in perpetuity, farmers in China and Vietnam are typically required to undertake land management activities with compensation as a redundant token for otherwise required activity.

The empirical evaluation of large scale government-run PES schemes as described here directs attention to the links between property rights arrangements, government or third party intervention, and transaction costs for a given PES initiative (Fig. 3). Because rural population densities in China and Vietnam are high with many small and individual land holdings not clearly defined, the costs of bringing parties together can be enormous (Huang et al. 2009). The vast administrative resources on which China prides itself are useful for promulgating large-scale payments programs such as the SLCP (Changjin and Liqiao 2007). Administrative authority can be used to force through the institutional resources necessary to engage in transactions even in the absence of long-term land ownership rights. These institutional resources include the involvement of village governments, farmer councils, and forest bureaus to coordinate and ideally deliberate on the terms and conditions of payments and management options specific to the social and ecological context. This would substantially reduce a proportion of transaction costs in bringing together service beneficiaries and providers for up-front negotiation, while at the same time avoiding a 'one size fits all' approach of the central government dictating conversion targets through devolved levels of government. The costs of bringing together stakeholders are termed external transaction costs, and essentially reflect the gap between existing social capital and individual agency for endogenously motivated land use change.

However, government control of transactions is unlikely to reduce total costs for PES. This is because of raised internal transaction costs associated with bureaucratic complexity, rent-seeking behavior, and path dependency of line agencies in administering the program (Changjin and Liqiao 2007). As mentioned, the lack of coordination between implementing agencies and clear delineation of specified tasks results in substantial overlap, conflicts of interest between agencies, and subsequent ineffectiveness of program implementation. As a result of broader fiscal reforms in China, local agencies charged with implementing the SLCP view subsidies as opportunities to finance their operations because they often lack the resource capacity to execute implementation of the program. Thus, local agencies have been prone to view 
Fig. 3. Depictions of two alternative scenarios for payments for ecosystem services (PES) as incentive-based negotiations or as government controlled payments. a) Under this scenario, the motivational driver for the transaction would be higher because service providers would be in the best position to negotiate based on demand and supply. This results in lower internal transaction costs (TCs). However, the costs of having many potential service providers and beneficiaries, developing contracts, as well as the technical support needed for fair and individualized trades would tend to inflate external transaction costs. b) In government-financed schemes, well-resourced governments can act to procure the provision of ecosystem services for the sake of public interest through subsidy payments. These programs can be implemented even in the absence of welldefined property rights, because governments can use a combination of regulatory and voluntary manoeuvres to encourage transactions. This administrative influence would tend to reduce external costs of mobilizing actors, negotiating and implementing contracts. However, the ambiguity in property rights and the dual role of government as intermediary and 'buyer' encourages principal-agent conflicts and rent-seeking behavior. In this case, the motivational driver for transactions would be lower, and hence internal transaction costs higher. Consequently, overall transaction costs could conceivably be of comparable size in both scenarios unless government shifts its role to an enabler of negotiations governed at the collective level in reducing both internal and external transaction costs (Xiaoyun et al. 2006).

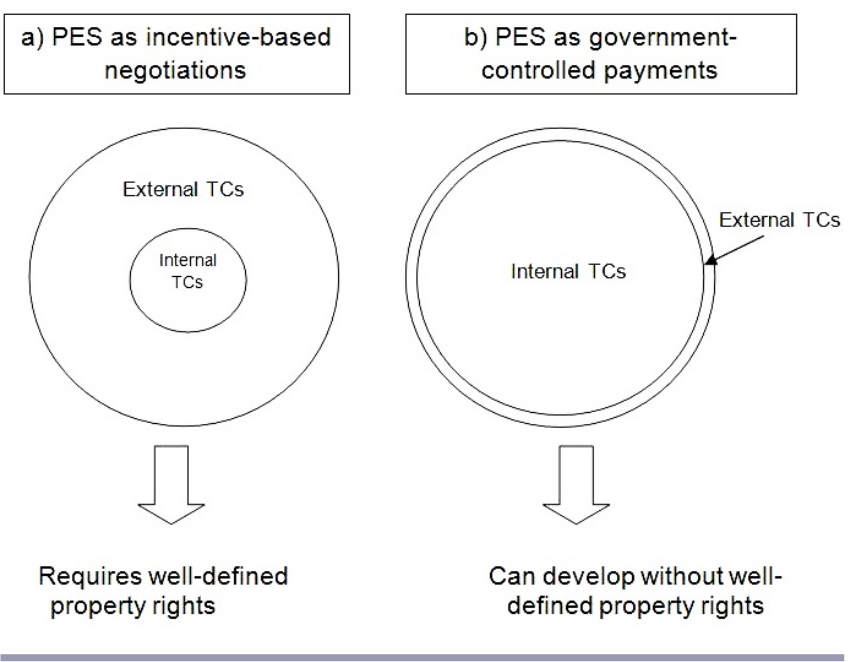

implementation requirements through a lens blurred by their fiscal woes, and this is reflected in rent-seeking by these agencies exaggerating estimates of implementation costs so as to inflate levels of subsidies provided from the central government (Groom et al. 2010, Xu et al. 2010a). Path dependency of these local agencies refers to rigid patterns of administration and implementing central government mandates. These established means are neither adaptive to changing circumstances nor questioned or deliberated internally or through participatory means (Rees 1990). Path dependency is a salient feature of the highly centralized governance models that remain ingrained in the socio-political history of China and Vietnam and will thus inevitably raise transaction costs when applying policy tools aimed at negotiating interests of stakeholders. As a result of such bureaucratic complexity, rent-seeking behavior, and path dependency, SLCP payments have not been delivered to recipients on time, there has been a lack of adequate monitoring and little consideration of ecologically appropriate planting and management (Huang et al. 2009). The conceptualization illustrated in Figure 3 suggests that PES would benefit by providing a foundation for endogenous development at minimal cost. In this way, overall transaction cost could be reduced if government implementing agencies shift their role from sole director and buyer on behalf of the whole public to facilitator or enabler of PES negotiations between stakeholders. Internal transaction costs can be reduced by streamlining the tasks of government agencies, providing legislative guidance for watershed goods and service negotiations to occur at a collective scale, and transferring adequate resources for implementation to village governments and farmer councils who can then represent individual households, ensuring that household well-being is met.

The lack of intrinsic motivation and poor empowerment of the parties to transactions suggests mounting internal transaction costs associated with maintaining payments over time through government control. High internally driven transaction costs can result from imperfect ecological targeting based on relatively standard subsidy payments across wide geographic regions that require considerable institutional resources, e.g., from governments or external donors, to implement. These aspects counter the efficiency gains associated with largescale roll out and simplicity in program design (Greiber 2009, Xu et al. 2010b). Although matching the cost-effectiveness of targeting payments to households may be costly and complex to determine in all areas where the SLCP has been implemented, we argue that there is a greater role for collective decision making at the local level. At the community level, decisions would reflect specific land use practices and livelihood concerns of farming households as a means to empower endogenous motivation for the de-cultivation of fragile sloping land. Self-initiated farmers' organizations remain a novel concept in China, but have recently been promoted with the Farmers Specialized Cooperative Organization Law in 2007, which has removed barriers for the promotion of dialogue between farmers and the creation of 
technical associations (Zhang et al. 2008). For example, in Ningxia Province, these associations, where developed, have focused on building capacity for farmers on crop and livestock issues, processing, irrigation, and transport. Given that $70 \%$ of the laborers involved in the SLCP are women, there is significant potential to enhance social capital to reflect stakeholder interests when bargaining for SLCP subsidies (Zhang et al. 2008). However, this would require greater central government recognition of the diversity of socioeconomic, ecological, farmer perceptions, and resource constraints that more accurately reflect SLCP implementation at the local level.

Closer inspection of the SLCP and Decision 380 pilots has raised two salient issues pertaining to the achievement of the environment and well-being advancement objectives of the PES concept. These issues refer to the mandatory versus voluntary nature of payments made by both service beneficiaries and service providers. Mandated payments from beneficiaries combined with mandated participation by service providers contradicts one of the critical characteristics of a PES-like approach and is certainly a backward step in the movement toward flexible approaches to natural resource governance that empower local communities to make strategic livelihood decisions.

The issue of mandatory versus voluntary is reflected differently in the two programs emerging from China and Vietnam. In the case of Decision 380, and subsequent Decree 99, the core objectives of choice in deciding collective futures is at question both from the perspective of forest dwellers and identified beneficiaries. In the case of the SLCP in China, the problem lies with state-directed conversion targets being usurped by local implementation agencies, and that supersede the interests and capacities of village councils that collectively possess ownership rights to the land. Thus, rather than affording voluntary participation rights to those groups possessing ownership rights, higher levels of government are dictating the participation of villages and households according to predetermined and ever-increasing conversion targets (Zhang et al. 2008) In both countries coercive payments rely precariously on political motivation that frequently deviates over time and thus has profound implications on the capabilities and opportunity sets available to households and communities (Pham et al. 2011). Accordingly, fully coerced payment programs have often led to government distrust by poor rural households (Weyerhaeuser et al. 2005, Grosjean and Kontoleon 2009, Petheram and Campbell 2010).

As China and Vietnam transition to market-oriented economies under inflexible command-style socio-political culture, a unique opportunity exists to design appropriate governance arrangements to manage natural resources by enhancing individuals' rights. We argue that the rise of individual agency to improve one's well-being through livelihood opportunities is embedded within social norms and collective understandings of long-term land and water stewardship (Ostrom 2005, Brondizio et al. 2009). Thus, the issue of mandatory versus voluntary payment resides in the opportunity for communities to voluntarily make decisions on participation that reflect the individual interests of their constituents. In Vietnam, communities are not recognized for land use management rights, while farmers and businesses are mandated to participate in a program in which the state has ownership rights on the payments collected from service beneficiaries. Instead, rights should be afforded to communities to collectively decide on household behavior in negotiating an incentive-based trade with service beneficiaries. Central government can aid this process by ensuring collective decision making is equitable, that terms of negotiation are adhered to and providing information to stakeholders to reduce costs of negotiation. In China, collective land use management rights do exist, but centrally mandated conversion targets override contextually specific ecological conditions and collective norms based on shared ownership rights to the land. Thus, the central governments of both countries need to recognize the institutional level at which governance of PES schemes best reflects shared understandings over land use and implementation to monitoring of land use practices over time. Government facilitation could be redirected toward providing community land use rights for ecological services such as water purification that provide collective benefits while promoting direct negotiation between contracting parties. This would represent a marginal step toward effective functioning in a context of government facilitation. Likewise, analyzing examples of voluntary behavior in highly regulated governance contexts would offer valuable insight on the extent and limitations of affording greater flexibility for the PES-like developments in China and Vietnam. Sustainable initiatives would also do better to focus less on monetary compensation for land use change and more on enhancing the well-being of service providers, including technical and agricultural extension support for land use transitioning, and empowering community-based institutions and individuals through microcredits and loans. Such a tactic would minimize principalagent conflicts associated with local government agencies acting on behalf of villages and households while also ensuring payments are usefully and sustainably invested to reflect the interests and deprivations of communities and individual households (Pirard et al. 2010). It would also ensure that the impressive political commitment and considerable public financing are leveraged for more strategic and flexible approaches for PES (Pham et al. 2009).

\section{CONCLUSION}

This comparative review of two national PES schemes in China and Vietnam raises a number of pertinent considerations about operationalizing incentive-based transactions for 
natural resource management amidst unique and evolving socio-cultural and political contexts. Two main questions have been raised: (1) What is the ideal role of government in PES schemes? (2) What are the implications of an absence of voluntary participation for PES administered by the government yet conceived as a social negotiation for ecosystem service management? As these nations emerge from centrally driven to more decentralized market-based economies, the role of government will need to shift from primary driver of mandatory transactions to strategic facilitator of negotiations that reflect service beneficiaries' requirements for watershed services and the compensation needs required by service providers for managing land for these services. The government can leverage the current scale of participation and experience across different institutional, geographic, and socioeconomic contexts to encourage those transactions that result in improved perceptions of watershed service delivery and that result in improved capabilities for service providers to enhance individual and community wellbeing. Such encouragement can come in the form of greater collective land-use security, transparent and available intermediaries to implement transactions, and ensuring the alignment of stakeholder needs and outcomes. If we consider that the lack of clear stipulations for voluntary participation in these schemes is a facet of the socio-cultural and political context in these countries, there may be an emerging opportunity as these countries continuously evolve to less centrally driven economies to filter those transactions that operate even in the absence of coercion because of intrinsic motivation that develops among and between stakeholders over time. Finally, it is necessary to consider whether longterm environmental and social improvements can be realized from short-term and highly variable government programs. If pilots and programs for incentive-based transactions can endow stakeholders with the resources or skills necessary to realize their perceptions of improved well-being through enhanced livelihood opportunities in lieu of retiring cultivation on marginal land, then stewardship of the land will have a higher likelihood to be sustained. However, this requires more investment in understanding the needs and desires of potential service providers and more locally targeted payment transactions. Thus, it is recommended that the vast political will that has led to the formation of these programs be channeled toward building sustained engagement and negotiation with local stakeholders in the aim of reducing both internal and external transaction costs over time.

${ }^{[1]}$ Managed as nature reserves, these forests are designated for the preservation of nature, forest ecosystems, genetic resources, scientific research, the protection of historical sites, and landscapes for tourism.

${ }^{[2]}$ Classified for the protection and regulation of water sources, climate regulation, erosion control, and the maintenance of ecological and environmental security.
${ }^{[3]}$ Considered for their economic value, particularly for timber (Wertz-Kanounnikoff and Rankine 2008).

Responses to this article can be read online at: http://www.ecologyandsociety.org/issues/responses. php/5057

\section{Acknowledgments:}

I would like to thank Dr. Andreas Wilkes of the Centre of Mountain Ecosystem Studies, Dr. Jin Leshan of the Chinese Agricultural University, Michael Bennett, senior researcher at Forest Trends, and Ms. Pham Thu Thuy of Charles Darwin University for their insights on the development of PES in China and Vietnam.

\section{LITERATURE CITED}

Agarwal, A., and E. Ostrom. 2001. Collective action, property rights, and decentralization in resource use in India and Nepal. Politics \& Society 29(4):485-514.

Banks, T., C. Richard, L. Ping, and Y. Zhaoli. 2003. Community-based grassland management in western China: rationale, pilot project experience, and policy implications. Mountain Research and Development 23(2):132-140. http:// dx.doi.org/10.1659/0276-4741(2003)023[0132:CGMIWC]2.0. $\mathrm{CO} ; 2$

Bennett, M. T. 2008. China's sloping land conversion program: institutional innovation or business as usual? Ecological Economics 65:699-711. http://dx.doi.org/10.1016/ j.ecolecon.2007.09.017

Bennett, M. T. 2009. Markets for ecosystem services in China: an exploration of China's "eco compensation" and other market-based environmental policies. Forest Trends, Washington, D.C., USA.

Bennett, M. T., A. Mehta, and J. Xu. 2011. Incomplete property rights, exposure to markets and the provision of environmental services in China. China Economic Review 22 (4):485-498. http://dx.doi.org/10.1016/j.chieco.2010.12.002

Bracer, C., S. Scherr, A. Molnar, M. Sekher, B. O. Ochieng, and G. Sriskanthan. 2007. Organization and governance for fostering pro-poor compensation for environmental services. CES Scoping Study Issue Paper no. 4. ICRAF Working Paper no. 39. World Agroforestry Centre, Nairobi, Kenya.

Brondizio, E. S., E. Ostrom, and O. R. Young. 2009. Connectivity and the governance of multilevel socialecological systems: the role of social capital. Annual Review of Environment and Resources 34:253-278. http://dx.doi. org/10.1146/annurev.environ.020708.100707 
Bruijnzeel, L. A. 2004. Hydrological functions of tropical forests: not seeing the soil for the trees? Agriculture, Ecosystems \& Environment 104(1):185-228. http://dx.doi. org/10.1016/j.agee.2004.01.015

Changjin, S., and C. Liqiao. 2007. A review of watershed environmental services from forest in China. Chapter 3 in L. Xiaoyun, J. Leshan, Z. Ting, and I. Bond, editors. Payment for watershed services in China: the role of government and market. Social Sciences Academic Press (China), Beijing, China.

Chen, X., F. Lupi, G. He, Z. Ouyang, and J. Liu. 2009. Factors affecting land reconversion plans following a payment for ecosystem service program. Biological Conservation 142 (8):1740-1747. http://dx.doi.org/10.1016/j.biocon.2009.03.012

Clements, T., A. John, K. Nielsen, D. An, S. Tan, and E. J. Milner-Gulland. 2010. Payments for biodiversity conservation in the context of weak institutions: comparison of three programs from Cambodia. Ecological Economics 69:1283-1291. http://dx.doi.org/10.1016/j.ecolecon.2009.11.010

Feng, Z., Y. Yang, Y.Zhang, P. Zhang, and Y. Li. 2005. Grainfor-green policy and its impacts on grain supply in west China. Land Use Policy 22(4):301-312. http://dx.doi.org/10.1016/j. landusepol.2004.05.004

Fu, B., G. Liu, X. Wang, and Z. Ouyang. 2004. Ecological issues and risk assessment in China. International Journal of Sustainable Development \& World Ecology 11(2):143-149. http://dx.doi.org/10.1080/13504500409469818

Gamez, L. 2007. Participation of utilities, private and public sectors in environmental services in Costa Rica. UNESCAP, Bangkok, Thailand. [online] URL: http://www.unescap.org/ esd/environment/services/meeting/2007 05 28/documents/ Presentations/Speakers Presentations Day1 28May07/5 LuisGamez_RACSA_28May07.pdf

Gillespe, J., and A. H. Y. Chen, editors. 2010. Legal reforms in China and Vietnam: a comparison of Asian Communist regimes. Routledge, New York, New York, USA.

Government of Vietnam. 2008. Decision No. 380/2008/QDTTg dated April, 2008 by the Prime Minister issuing The Pilot Policy for Payment for Forest Ecosystem Services. Government of Vietnam, Hanoi, Vietnam.

Government of Vietnam. 2010. Mid-Term Evaluation Report On the implementation of the Decision 380/2008/QD-TTg dated 4 April 2008 of the Prime Minister on the policy for Payment for Forest Ecosystem Services. Ministry of Agriculture and Rural Development, Government of Vietnam, Hanoi, Vietnam.
Greiber, T., editor. 2009. Payments for ecosystem services. Legal and institutional frameworks. International Union for Conservation of Nature, Gland, Switzerland.

Grosjean, P., and A. Kontoleon. 2009. How sustainable are sustainable development programs? The case of the sloping land conversion program in China. World Development 37 (1):268-285. http://dx.doi.org/10.1016/j.worlddev.2008.05.003

Groom, B., P. Grosjean, A. Kontoleon, T. Swanson, and S. Zhang. 2010. Relaxing rural constraints: a 'win-win' policy for poverty and environment in China? Oxford Economic Papers 62(1):132-156. http://dx.doi.org/10.1093/oep/gpp021

Hoang, M. H., M. Van Noordwijk, and T. T. Pham. 2008. Payment for environmental services: experiences and lessons in Vietnam. World Agroforestry Centre (ICRAF), Hanoi, Vietnam.

Huang, M., S. K. Upadhyaya, R. Jindal, and J. Kerr. 2009. Payments for watershed services in Asia: a review of current initiatives. Journal of Sustainable Forestry 28(3-5):551-575. http://dx.doi.org/10.1080/10549810902794287.

Jiao, J., Z. Zhang, W. Bai, Y. Jia, and N. Wang. 2012. Assessing the ecological success of restoration by afforestation on the Chinese Loess Plateau. Restoration Ecology 20(2):240-249. http://dx.doi.org/10.1111/ j.1526-100X.2010.00756.X

Li, C., J. Qi, Z. Feng, R. Yin, B. Guo, F. Zhang, and S. Zou. 2010. Quantifying the effect of ecological restoration on soil erosion in China's Loess Plateau region: an application of the MMF approach. Environmental Management 45:476-487. http://dx.doi.org/10.1007/s00267-009-9369-6

Liss, B.-M. 2008. Development and application of a pilot policy on payment for environmental services (PES) in Da River Basin, Son La Province. Report on Consultancy Mission, Vietnamese-German Technical Cooperation (GTZ), Hanoi, Vietnam.

Liu, J., and J. Diamond. 2005. China's environment in a globalizing world. Nature 435:1179-1186. http://dx.doi. org/10.1038/4351179a

Long, H. L., G. K. Heilig, J. Wang, X. B. Li, M. Luo, X. Q. $\mathrm{Wu}$, and M. Zhang. 2006. Land use and soil erosion in the upper reaches of the Yangtze River: some socio-economic considerations on China's Grain-for-Green Programme. Land Degradation \& Development 17:589-603. http://dx.doi. org/10.1002/ldr.736

Nguyen, T. B. T., C. T. Nguyen, P. T. Nguyen, T. N. Pham, D. Bonnardeaux, and D. C. Riedel. 2011. Payment for forest environmental services: a case study on pilot implementation 
in Lam Dong Province, Vietnam 2006-2010. Winrock International, Little Rock, Arkansas, USA. [online] URL: http://www.winrock.org/fnrm/files/PaymentForForestEnvironmentalServicesARBCPCaseStudy.pdf

Nguyen, V. D., I. Douglas, J. McMorrow, S. Lindley, D. Kim, T. B. Nguyen, T. V. Tran, H. T. Le, and T. Nguyen. 2008. Erosion and nutrient loss on sloping land under intense cultivation in southern Vietnam. Geographical Research 46 (1):4-16. http://dx.doi.org/10.1111/j.1745-5871.2007.00487. $\underline{x}$

Ostrom, E. 1990. Governing the commons: the evolution of institutions for collective action. Cambridge University Press, Cambridge, UK. http://dx.doi.org/10.1017/CBO9780511807763

Ostrom, E. 2005. Understanding institutional diversity. Princeton University Press, Princeton, New Jersey, USA.

Pagiola, S., and G. Platais. 2007. Payments for environmental services: from theory to practice. World Bank, Washington, D.C., USA.

Painter, M. 2008. From command economy to hollow state? Decentralisation in Vietnam and China. Australian Journal of Public Administration 67(1):79-88. http://dx.doi.org/10.1111/ j.1467-8500.2007.00570.x

People's Republic of China (PRC). 2005. Law of the People's Republic of China on Land Contract in Rural Areas (Order of the President No.73). People's Republic of China, Beijing, China. [online] URL: http://www.gov.cn/english/2005-10/09/ content 179389.htm

Petheram, L., and B. M. Campbell. 2010. Listening to locals on payments for environmental services. Journal of Environmental Management 91:1139-1149. http://dx.doi. org/10.1016/j.jenvman.2010.01.002

Pham, T. T., B. M. Campbell, and S. Garnett. 2009. Lessons for pro-poor payments for environmental services: an analysis of projects in Vietnam. Asia Pacific Journal of Public Administration 31(2):117-133.

Pham, T. T., B. M. Campbell, S. Garnett, H. Aslin, and M. H. Hoang. 2010. Importance and impacts of intermediary boundary organizations in facilitating payment for environmental services in Vietnam. Environmental Conservation 37:64-72. http://dx.doi.org/10.1017/ $\underline{\text { S037689291000024X }}$

Pham, T. T., S. T. Garnett, and H. Aslin. 2011. Organisational and institutional opportunities and constraints for poor households to participate in payment for environmental service schemes in Vietnam. Asia Pacific Journal of Public Administration 33:1-19.

Pham, T. T., M. H. Hoang, and B. M. Campbell. 2008. Propoor payments for environmental services: challenges for the government and administrative agencies in Vietnam. Public
Administration and Development 28(5):363-373. http://dx. doi.org/10.1002/pad.513

Pirard, R., and R. Billé. 2010. Payments for environmental services (PES): a reality check (stories from Indonesia). No. 3. Institut du développement durable et des relations internationales (IDDRI), Paris, France.

Pirard, R., R. Billé, and T. Sembrés. 2010. Upscaling payments for environmental services (PES): critical issues. Tropical Conservation Science 3(3):249-261.

Postel, S. L., and B. H. Thompson, Jr. 2005. Watershed protection: capturing the benefits of nature's water supply services. Natural Resources Forum 29:98-108. http://dx.doi. org/10.1111/j.1477-8947.2005.00119.x

Rees, J. 1990. Natural resources allocation, economics and policy. Second Edition. Routledge, London, UK.

Salzman, J. 2005. Creating markets for ecosystem services: notes from the field. New York University Law Review 80 (6):870-954.

Scherr, S., M. Bennett, M. Loughney, and K. Canby. 2006. Developing future ecosystem services payments in China: lessons from international experience. Forest Trends, Washington, D.C., USA. [online] URL: http://www. foresttrends.org/documents/files/doc 99.pdf

Tao, R., and P. Qin. 2007. How has rural tax reform affected farmers and local governance in China? China \& World Economy 15(3):19-32. http://dx.doi.org/10.1111/ j.1749-124X.2007.00066.X

Tao, W., S. Zhang, C. Ai, Y. Peng, S. Zhu, and X. Xie. 2007. The analysis of effectiveness on policy making and implementation of the Sloping Land Conversion Program. China Population, Resources, and Environment 4:66-70.

Uchida, E., J. Xu, and S. Rozelle. 2005. Grain for green: costeffectiveness and sustainability of China's conservation setaside program. Land Economics 81(2):247-264.

Uchida, E., J. Xu, Z. Xu, and S. Rozelle. 2007. Are the poor benefitting from China's land conservation program? Environment and Development Economics 12(4):593-620. http://dx.doi.org/10.1017/S1355770X07003713

Van An, D., and L. M. Duc. 2007. Economic reforms in China and Vietnam: a brief comparison. Central Institute for Economic Management, Hanoi, Vietnam.

Vu, K. M. 2009. Economic reform and growth performance: a comparative study of China and Vietnam. China: An International Journal 7(2):189-226.

Wang, X., H. Han, and J. Bennett. 2004. China's land use management. Research Report no. 1. Australian Centre for International Agricultural Research, Canberra, Australia. 
Wertz-Kanounnikoff, S., and H. Rankine. 2008. How can governments promote strategic approaches to payments for environmental services (PES)? An exploratory analysis for the case of Viet Nam. No. 3. Institut du développement durable et des relations internationales (IDDRI), Paris, France.

Weyerhaeuser, H., A. Wilkes, and F. Kahrl. 2005. Local impacts and responses to regional forest conservation and rehabilitation programs in China's northwest Yunnan province. Agricultural Systems 85:234-253. http://dx.doi. org/10.1016/j.agsy.2005.06.008

Wu, G., and M. Ding. 2003. The 5-year implementation of the sloping farming lands conversion program has enabled a winwin for local development. Xinhua News Agency 9 December. [online] URL: http://news.xinhuanet.com/fortune/2003-12/09/ content 1221350 .htm

Wunder, S. 2005. Payments for environmental services: some nuts and bolts. CIFOR Occasional Paper No. 42. Center for International Forestry Research, Bogor, Indonesia.

Wunder, S., D. T. Bui, and E. Ibarra. 2005. Payment is good, control is better. Why payments for forest environmental services in Vietnam have so far remained incipient. Center for International Forestry Research, Bogor, Indonesia.

Xiaoyun, L., J. Leshan, Z. Ting, and I. Bond. 2006. Payment for watershed services in China: the role of government and market. Social Sciences Academic Press (China), Beijing, China.

Xu, J., R. Tao, Z. Xu, and M. Bennett. 2010a. China's sloping land conversion program: does expansion equal success? Land Economics 86(2):219-244.

Xu, J., R. Yin, Z. Li, and C. Liu. 2006a. China's ecological rehabilitation: unprecedented efforts, dramatic impacts, and requisite policies. Ecological Economics 57:595-607. http:// dx.doi.org/10.1016/j.ecolecon.2005.05.008

Xu, J., H. Zhang, J. Bennett, X. Wang, and M. Eigenraam. 2010b. Ecological afforestation in China: a market-based approach. Environment for Development China, Beijing, China. [online] URL: http://www.efdinitiative.org/research/ publications/publications-repository/ecological-afforestationin-china-a-market-based-approach

Xu, Z., M. T. Bennett, R. Tao, and J. Xu. 2004. China's sloping land conversion program four years on: current situation pending issues. International Forestry Review 6(3-4):317-326. http://dx.doi.org/10.1505/ifor.6.3.317.59976

Xu, Z., J. Xu, X. Deng, J. Huang, E. Uchida, and S. Rozelle. 2006b. Grain for green versus grain: conflict between food security and conservation set-aside in China. World Development 34(1):130-148. http://dx.doi.org/10.1016/j. worlddev.2005.08.002
Xuan, P., and C. Santiago. 2010. Vietnam leads Southeast Asia in payments for ecosystem services. Ecosystem Marketplace, Washington, D.C., USA. [online] URL: http://www. ecosystemmarketplace.com/pages/dynamic/article.page.php? page $\mathrm{id}=7593 \&$ section $=$ news articles\&eod $=1$

Zhang, L., Q. Tu, and A. P. J. Mol. 2008. Payment for environmental services: the sloping land conversion program in Ningxia Autonomous Region of China. China \& World Economy 16(2):66-81. http://dx.doi.org/10.1111/ j.1749-124X.2008.00107.X

Zhao, L. 2008. Study on the living offarmers involved in 'Grain for Green' national key forestry program in Yunnan Province. World Forest Institute, Portland, Oregon, USA. [online] URL: http://wfi.worldforestry.org/media/presentations/china 1.zhao. pdf

Zheng, H., and L. Zhang. 2006. Chinese practices of ecological compensation and payments for ecological and environmental services and its policies in river basins. World Bank, Washington, D.C., USA. [online] URL: http:// siteresources.worldbank.org/INTEAPREGTOPENVIRONMENT/ Resources/ReportPESreviewChinesepracticeCAASFinalENFINAL. pdf

Zilberman, D. V. 2007. Payments for environmental services: who gains who loses? Agricultural and Resource Economics Update 11(1):1-3. 